\title{
PHOSPHORIBOISOMERASE FROM SUGARCANE LEAVES
}

Little literature exists concerning the isolation and purification of phosphoriboisomerase. Benson et al. ${ }^{1}$ identified the presence of seven and five carbon compounds for the first time. The role of these compounds in the photosynthetic carbon reduction pathway became clear in 1954 with the work reported by Bassham et al.2

Horecker et al..$^{3}$ detected the presence of pentose phosphate isomerase in yeast. This report was followed by that of Axelrod and Jang, ${ }^{4}$ who investigated the presence of this enzyme in tissues of higher plants, such as pea leaf, alfalfa, orange flavedo, spinach leaf and avocado leaf and fruit. Hurwitz et al. ${ }^{5}$ purified phosphoriboisomerase from spinach leaf extracts. Chen et al. ${ }^{6}$ studied the enzymatic changes in dark-grown cornleaves. Alexander and Montalvo-Zapata ${ }^{7,8}$ postulated that there is a block at the site of phosphoriboisomerase action in sugarcane desiccated with Paraquat and Diquat.

It has been possible for us to detect the presence of phosphoriboisomerase in the leaves of sugarcane, using the method of Axelrod and Jang. ${ }^{4}$ Fractionation of the cane leaf extract revealed that most of the protein containing phosphoriboisomerase was precipitated between 40 to 50 percent saturation by ammonium sulfate.

Activity of sugarcane phosphoriboisomerase was studied within a broad $\mathrm{pH}$ range from 5.0 to 9.0. The $\mathrm{pH}$ optimum for the enzyme reaction was 8.5 (table 1). For alfalfa the optimum $\mathrm{pH}$ was $7.0^{4}$ and for spinach 7.1.5

1 Benson, A. A., Bassham, J. A., Calvin, M., Hall, A. G., Hirsch, H. E., Kawaguchi, S., Lynch, V. H., and Tolbert, N. E., The path of carbon in photosynthesis. XV. Ribulose and sedoheptulose, J. Biol. Chem. 196(2) : 703-16, 1952.

2 Bassham, J. A., Benson, A. A., Kay, L. D., Harris, A. Z., Wilson, A. T., and Calvin, M., The path of carbon in photosynthesis. XXI. The cyclic regeneration of carbon dioxide accepter, J. Am. Chem. Soc. 76(7): 1760-70, 1954.

'Horecker, B. L., Smyrniotis, P. Z., and Seegmiller, J. E., The enzymatic conversion of 6-phosphogluconate to ribulose-5-phosphate and ribose-5-phosphate, $J$. Biol. Chem. $198(1)$ : 383-96, 1951.

4 Axelrod, B., and Jang, R., Purification and properties of phosphoriboisomerase from alfalfa, $J$. Biol. Chem. $209(2): 847-55,1954$.

5 Hurwitch, J., Weissbach, A., Horecker, B. L., and Smyrniotis, P. Z., Spinach phosphoribulokinase, J. Biol. Chem. 218(2): 769-83, 1956.

- Chen, S., McMahon, D., and Bogorad, L., Early effects of illumination on the activity of some photosynthetic enzymes, Plant Physiol. 4R(1): 1-5, 1967.

7 Alexander, A. G., and Montalvo-Zapata, R., Enzyme studies of sucrose decline in sugarcane desiccated with paraquat, J.Agr. Univ. P. R. 58(4): 230-50, 1969.

8 Alexander, A. G., and Montalvo-Zapata, R., Enzymatic factors in the sucrose decline of sugarcane desiccated with paraquat, diquat, and dinitrobutylphenol, $J . A g r$.
Univ. P. R. $54(1): 28-49,1970$. 
TABLE 1.-Effect of variable $p H$ upon phosphoriboisomerase from leaves of sugarcane ${ }^{1}$

\begin{tabular}{lccccccccc}
\hline & \multicolumn{8}{c}{ PI (mg. $\times 108 / 30$ minutes) at pH- } \\
\cline { 2 - 9 } & 5.0 & 5.5 & 6.0 & 6.5 & 7.0 & 7.5 & 8.0 & 8.5 & 9.0 \\
\hline $\begin{array}{c}\text { Phosphoribo- } \\
\text { isomerase }\end{array}$ & 10.1 & 11.2 & 11.2 & 11.2 & 9.6 & 13.9 & 14.5 & 16.5 & 16.2 \\
\hline
\end{tabular}

1 The conditions differed from those in the standard assay in that Ba-free-R-5-P was used as substrate and tris buffer omitted. The pH of the substrate was adjusted with $2 \mathrm{~N} \mathrm{NaOH}$ or $2 \mathrm{~N} \mathrm{HCl}$.

Detailed investigations relating to other properties and purification are in progress and will be presented later.

Ashok Kumar and Alex G. Alexander Department of Agronomy and Soils

\section{Erratum}

Please note that the third line, page 208, in the paper EFFECT OF ZONE AND CLIMATE ON YIELD, QUALITY AND RIPENING CHARACTERISTICS OF MONTECRISTO BANANAS GROWN IN PUERTO RICO by F. Sanchez Nieva et al., which appeared in J. Agr. Univ. P.R. 53 (4): 195-210, 1970 is in error:

Where it reads "while at Adjuntas", it should read "while at Fortuna". 